\title{
An in-situ method to estimate the tip temperature and phase selection of secondary Fe-rich intermetallics using synchrotron X-ray radiography
}

\author{
S. Feng *, E. Liotti, A. Lui, S. Kumar, A. Mahadevegowda, K.A.Q. O'Reilly, P.S. \\ Grant \\ Department of Materials, University of Oxford, Oxford OX1 3PH, UK
}

\begin{abstract}
A method was developed based on synchrotron X-ray radiography to estimate tip temperatures of 203 Fe-rich intermetallic compound (IMC) particles during directional solidification of Al-Cu-Fe alloys. Tip temperatures showed two distinct IMC populations corresponding to $\mathrm{Al}_{6}(\mathrm{Fe}, \mathrm{Cu})$ and $\mathrm{Al}_{7} \mathrm{Cu}_{2} \mathrm{Fe}$, validated by post-solidification microscopy. The IMC tip undercooling of each growing IMC was estimated by comparison with its equilibrium formation temperature. The effect of Fe concentration, cooling rate and grain refiner additions on the IMC tip undercooling was studied. With a large number of IMC particles measured, we show the relationship between solidification parameters, secondary IMC selection and tip undercooling.

Keywords: Intermetallics; Tip temperature; Phase selection; Al alloys; Synchrotron X-ray radiography
\end{abstract}

X-ray radiography is used increasingly to study the solidification dynamics of $\mathrm{Al}$ alloys, for example to investigate the fragmentation of primary $\alpha$-Al dendrites [1, 2], growth of secondary intermetallic compound (IMC) particles [3], growth [4] and fragmentation [5] of primary IMC particles, and bubble formation [6]. In all these studies, the temperature during the alloy solidification was measured indirectly by measuring the temperature of heating elements, while the actual temperature of the sample was only inferred. While this issue may not be significant for qualitative studies of growth 
or fragmentation rate, it is crucial when studying strongly temperature-related phenomena such as nucleation, growth undercooling and phase transformations. In this paper, we present an in-situ approach based on real-time X-ray radiography to estimate the temperature at any time and position in the field of view. This method was then applied to obtain tip temperatures of 203 secondary Fe-rich IMC particles during directional solidification of Al-10 wt.\% Cu alloys with two different Fe concentrations, showing significant IMC tip undercoolings and different IMC phase selection.

Al-Cu alloys containing 2-10 wt.\% Cu, with other alloying additions, were one of the first and most widely used engineering Al alloys, now known as 2xx.x cast and 2xxx wrought alloys [7]. The presence of impurity elements such as Fe, which is picked up during primary production or more frequently from recycling processes and which has low solid solubility in $\mathrm{Al}$, usually combined with $\mathrm{Al}$ and $\mathrm{Cu}$, leads to the formation of coarse, insoluble and faceted Fe-rich IMCs during later stages of solidification. These IMC phases include $\mathrm{Al}_{6}(\mathrm{Fe}, \mathrm{Cu})$ and $\mathrm{Al}_{7} \mathrm{Cu}_{2} \mathrm{Fe}$, which can form at Fe concentration as low as 0.03 wt.\% [8], well below the Fe concentration limit in $2024 \mathrm{Al}$ alloy (0.5 wt.\%), which is widely used in the aerospace industry. In the 1980's, Backerud et al. [8] observed $\mathrm{Al}_{6}(\mathrm{Fe}, \mathrm{Cu})$ as the first IMC to form, which then transformed into $\mathrm{Al}_{7} \mathrm{Cu}_{2} \mathrm{Fe}$ in 206 cast Al with 0.03 wt.\% Fe. Similar results have been reported [9 11] in cast $\mathrm{Al}-\mathrm{Cu}$ alloys with $\mathrm{Fe}$ concentration up to 0.3 wt.\%, indicating only $\mathrm{Al}_{7} \mathrm{Cu}_{2} \mathrm{Fe}$ or the co-existence of both $\mathrm{Al}_{6}(\mathrm{Fe}, \mathrm{Cu})$ and $\mathrm{Al}_{7} \mathrm{Cu}_{2} \mathrm{Fe}$ in the final microstructure. In cast Al-Cu alloys with higher Fe concentrations (>0.3 wt.\%), more diverse Fe-rich IMCs were reported [12 14 depending on the solidification conditions. These faceted and relatively insoluble IMCs can degrade alloy ductility and toughness by acting as stress raisers and crack initiators [14-16], and may also cause severe localised corrosion in high-end aerospace alloys [17 20$]$. Nonetheless, a complete understanding of the factors controlling IMC phase nucleation, growth and how they vary with composition, 
solidification conditions, etc has yet to be developed, largely due to the restriction of only being able to infer nucleation and growth behaviour from post-solidification microscopy and other qualitative techniques.

With real-time X-ray radiography and an in-situ temperature estimation approach, we show directly from the radiographs that different Fe-rich IMCs formed and grew at a range of tip undercoolings, depending upon cooling rate and grain refiner additions, which in turn affected phase selection and the final IMC population.

Real-time synchrotron X-ray radiography studies during the solidification of Al-CuFe alloys were carried out at beamline B16 at the Diamond Light Source, UK, with a monochromatic beam energy of $18 \mathrm{keV}$. Radiography videos were recorded with a PCO.Edge camera at a frame rate of $7.5 \mathrm{fps}$ with a spatial resolution of $1.65 \mu \mathrm{m} / \mathrm{pixel}$. All experiments used the solidification rig that is described in detail in [1]. Briefly, the rig consisted of a Bridgman furnace with two vertically aligned plate heaters. A $200 \mu \mathrm{m}$ thick sample sectioned from a bulk casting was encapsulated in a quartz cell and positioned onto the plate heaters. Fig. 11 shows a photograph of the Bridgman furnace together with a schematic of the arrangement. The sample was fully melted and held isothermally at $750^{\circ} \mathrm{C}$ for 3 minutes, and then a constant pre-selected thermal gradient of $35 \mathrm{~K} \mathrm{~mm}^{-1}$ was imposed between the two heaters, following which directional solidification from the bottom to the top was achieved by cooling both heaters at a predetermined rate (while maintaining the constant temperature gradient of $35 \mathrm{~K} \mathrm{~mm}^{-1}$ between the heaters), through the alloy solidification temperature range. $10 \mathrm{Cu}-1.5 \mathrm{Fe}$ and $\mathrm{Al}-10 \mathrm{Cu}-0.8 \mathrm{Fe}$ at cooling rates ranging from $0.1 \mathrm{Ks}^{-1}$ to $2 \mathrm{Ks}^{-1}$. For each alloy composition, samples without and with a $\mathrm{TiB}_{2}$ grain refiner $(0.1 \mathrm{wt} \% \mathrm{Al}-5 \mathrm{Ti}-$ 1B) were prepared. Table 1 summarises the experiments and the number of repeats of each. For convenience and as shown in Table 1 , the different alloy samples are named as: 

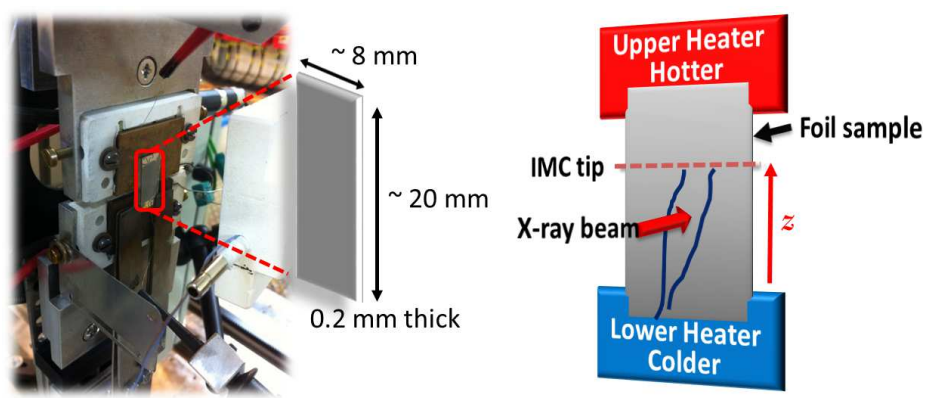

Figure 1: The Bridgman furnace heaters and a schematic of the sample arrangement.

\begin{tabular}{lccccccc}
\hline & \multirow{2}{*}{$\begin{array}{c}\text { Alloy } \\
\text { Name }\end{array}$} & & \multicolumn{5}{c}{ Cooling rate $\left(\mathbf{K s}^{-1}\right)$} \\
\cline { 5 - 8 } & Composition & Refined & 0.1 & 0.2 & 0.6 & 1 & 2 \\
\hline $0.8 \mathrm{Fe}$ & \multirow{2}{*}{$\mathrm{Al}-10 \mathrm{Cu}-0.8 \mathrm{Fe}$} & - & - & $4(12)$ & $3(9)$ & $2(8)$ & - \\
$0.8 \mathrm{Fe}-\mathrm{GR}$ & & $\mathrm{TiB}_{2}$ & - & $4(20)$ & $2(10)$ & $2(12)$ & - \\
$1.5 \mathrm{Fe}$ & & - & $4(25)$ & $7(33)$ & $6(25)$ & $3(12)$ & - \\
$1.5 \mathrm{Fe}-\mathrm{GR}$ & \multirow{2}{*}{$\mathrm{Al}-10 \mathrm{Cu}-1.5 \mathrm{Fe}$} & $\mathrm{TiB}_{2}$ & - & $3(8)$ & $3(11)$ & $2(10)$ & $2(8)$ \\
\hline
\end{tabular}

Table 1: Experimental parameter summary for the 47 experiments showing the number of repeats in each condition and the number of individual intermetallic particles identified (in parenthesis). Overall, 203 particles were analysed. All compositions are in wt\%. In the grain refined alloys, $0.1 \mathrm{wt} \%$ of Al-5Ti-1B was added to the bulk castings.

1.5Fe, 0.8Fe, 1.5Fe-GR and 0.8Fe-GR. A high Cu concentration of 10 wt.\% (equivalent to high-Cu cast $\mathrm{Al}$ alloy used for aircraft cylinder head and cylinder blocks [7]) and high Fe concentrations of 0.8 wt.\% and 1.5 wt.\% (max. Fe concentration in 2xx.x Al cast alloy) were employed with the intention of: (a) forming a relatively high fraction of $\mathrm{Al}_{6}(\mathrm{Fe}, \mathrm{Cu})$ and $\mathrm{Al}_{7} \mathrm{Cu}_{2} \mathrm{Fe}$, which are the IMCs of interest, to facilitate their observation and measurement; and (b) obtaining sufficient X-ray absorption contrast between the IMCs enriched in both $\mathrm{Fe}$ and $\mathrm{Cu}$, the Al-rich primary phase, and the $\mathrm{Cu}$-rich liquid.

Two K-type thermocouples were used in the experiments to monitor the temperature of the two heaters, but the precise temperature in the sample itself was not available. Therefore, a method was developed that allowed estimation of the temperature at any 70 point in the field of view. First, by assuming that for steady-state dendritic growth at low solidification velocity (i.e. low cooling rate), constitutional supercooling at the dendrite tip may be ignored $\left(<1.3^{\circ} \mathrm{C}\right)$, the primary $\alpha$-Al dendrite tips were considered 
always to be growing (from bottom to top) at the alloy liquidus temperature. This maximum value of $1.3^{\circ} \mathrm{C}$ was determined by measuring the solute concentration in the tip region at the highest cooling rate, and relating concentration to tip temperature via the phase diagram, and for most experiments was $<1^{\circ} \mathrm{C}$. Second, the liquidus temperature for the alloys studied was determined from ternary Al-Cu-Fe phase diagram to be $627^{\circ} \mathrm{C}$, with a difference of only $1^{\circ} \mathrm{C}$ for the different Fe concentrations of 1.5 and 0.8 wt\%, which was much less than the difference in the varying IMC growth temperatures subsequently recorded. Then in each experiment, the dendrite tips were tracked from image to image as they grew upwards with a well-defined tip front. Finally, by combining the known dendrite tip temperature with the accurately controlled constant cooling rate of the heaters, the temperature field behind the dendrite front was estimated for every image.
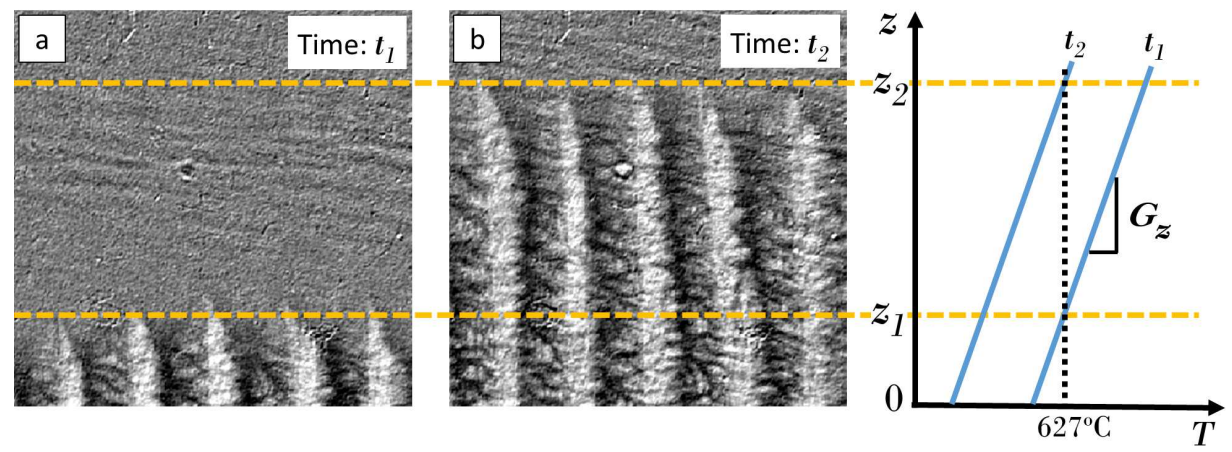

Figure 2: Radiographs of $0.8 \mathrm{Fe}$ at $0.2 \mathrm{Ks}^{-1}$ and a schematic showing how the temperature field was estimated.

Figs. $2 \mathrm{a}$ and $2 \mathrm{~b}$ show two radiographs taken from the solidification of $0.8 \mathrm{Fe}$ at cooling rate $\dot{T}=0.2 \mathrm{Ks}^{-1}$. Time $t=0$ was when the $\alpha$-Al dendrite tips first appeared at the bottom of the field of view at vertical height $z=0$. At time $t=t_{1}>0$, the $\alpha$-Al dendrite tips were at position $z=z_{1}$ with a dendrite tip temperature of $T\left(z_{1}, t_{1}\right)=627^{\circ} \mathrm{C}$. At $t=t_{2}>t_{1}$, the dendrite tips had grown upwards to position 90 $z_{2}$, and the temperature at $z_{2}$ was $T\left(z_{2}, t_{2}\right)=627^{\circ} \mathrm{C}$, while the temperature at $z_{1}$ had 
reduced to $T\left(z_{1}, t_{2}\right)=627^{\circ} \mathrm{C}-\dot{T} \times\left(t_{2}-t_{1}\right)$.

The 1-D temperature gradient in the $z$ direction $G_{z}$, where $G_{z}$ is positive along positive $z$ direction, was therefore given by:

$$
G_{z}=\frac{T\left(z_{2}, t_{2}\right)-T\left(z_{1}, t_{2}\right)}{z_{2}-z_{1}}=\frac{627-\left[627-\dot{T} \times\left(t_{2}-t_{1}\right)\right]}{z_{2}-z_{1}}=\frac{\dot{T} \times\left(t_{2}-t_{1}\right)}{z_{2}-z_{1}}
$$

Thus, the temperature $T(z, t)$ at any vertical distance $z$ in the field of view at time $t$ was estimated by:

$$
T(z, t)=627-\dot{T} t+G_{z} z=627+\dot{T} \times\left[\frac{z}{z_{2}-z_{1}} \times\left(t_{2}-t_{1}\right)-t\right]
$$

Consequently $T(z, t)$ was independent of the absolute heater temperatures, and dependent only on the differential of the temperature with respect to time i.e. the cooling rate, which was accurately controlled. By assuming there were no temperature gradients in directions normal to the $z$ direction, the positions of the IMC tip in each frame could directly be associated with an instantaneous temperature at that point. IMC tip position was tracked and recorded by eye directly from the radiographic image sequences for each of the different cooling rates in each of the alloy compositions using a mouse-click with a bespoke Matlab (MathWorks, USA) code. By tracking the position of individual IMC tips frame-by-frame this way and following the procedure of temperature calibration described above, the IMC tip temperature for every identified IMC tip in each image was estimated and recorded, with an accuracy estimated at $\pm 3^{\circ} \mathrm{C}$.

Post-solidification phase identification was carried out using transmission electron microscopy (TEM; JEOL-3000F, Japan Electron Optics Ltd., Tokyo, Japan) and scanning electron microscopy (SEM; JEOL JSM-5510 LV, Japan Electron Optics Ltd., Tokyo, Japan), in conjunction with energy dispersive X-ray spectroscopy (EDX) to 
identify the specific IMC types for each combination of alloy composition, grain refiner addition and cooling rate. Composition measurements by EDX were performed at an acceleration voltage of $20 \mathrm{kV}$, beam spot diameter of $60 \mathrm{~nm}$, working distance of 20 $\mathrm{mm}$ and live time of 100s, using K $\alpha$ fluorescence. Standardless K-line EDX analysis is widely accepted for major elements to have an accuracy of $\sim 1 \%$ [21]. Compositional data were acquired from 118 acquisition points in 34 individual IMC particles (3-4 acquisition points in each IMC). Monte Carlo electron trajectory simulations (Casino v2.48) were performed to estimate the size of the X-ray-sample interaction volume for $\mathrm{Al}_{7} \mathrm{Cu}_{2} \mathrm{Fe}$, which was one of the most commonly observed IMCs in the alloys, with input parameters (acceleration voltage, beam spot size, etc.) consistent with those under which the EDX spectra were acquired. The interaction volume was approximately 2.4 $\mu \mathrm{m}$ wide and $2 \mu \mathrm{m}$ deep, and considered acceptable when compared with typical size of the IMCs.

Fig. $3 \mathrm{a}$ shows an example radiograph sequence of IMC growth in $0.8 \mathrm{Fe}$ at $0.2 \mathrm{Ks}^{-1}$. The morphology of the $\alpha$-Al primary phase was columnar because of the strong 1-D temperature gradient, growing bottom to top, and the IMCs grew along/in the interdendritic channels between columnar grains with a straight, needle-like morphology. Following the method described earlier, Fig. 3b shows IMC tip temperature versus cooling rate for 203 IMCs from all experiments.

Non-grain refined $1.5 \mathrm{Fe}$ showed two clusters of IMC tip temperature at each cooling rate, suggesting the presence of two types of IMCs. The "high-T" IMC had a tip temperature of $614 \pm 6^{\circ} \mathrm{C}, 611 \pm 8^{\circ} \mathrm{C}, 614 \pm 5^{\circ} \mathrm{C}$ and $614 \pm 1^{\circ} \mathrm{C}$, while the "low-T" IMC had a tip temperature of $592 \pm 3^{\circ} \mathrm{C}, 589 \pm 5^{\circ} \mathrm{C}, 593 \pm 3^{\circ} \mathrm{C}$ and $592 \pm 2^{\circ} \mathrm{C}$, as the cooling rate 130 increased from $0.1 \mathrm{Ks}^{-1}$ to $1 \mathrm{Ks}^{-1}$. Thus within each of these populations, there was no significant variation in tip temperature with increasing cooling rate. The lower Fe concentration non-grain refined $0.8 \mathrm{Fe}$ also showed a single range of IMC tip temperatures 

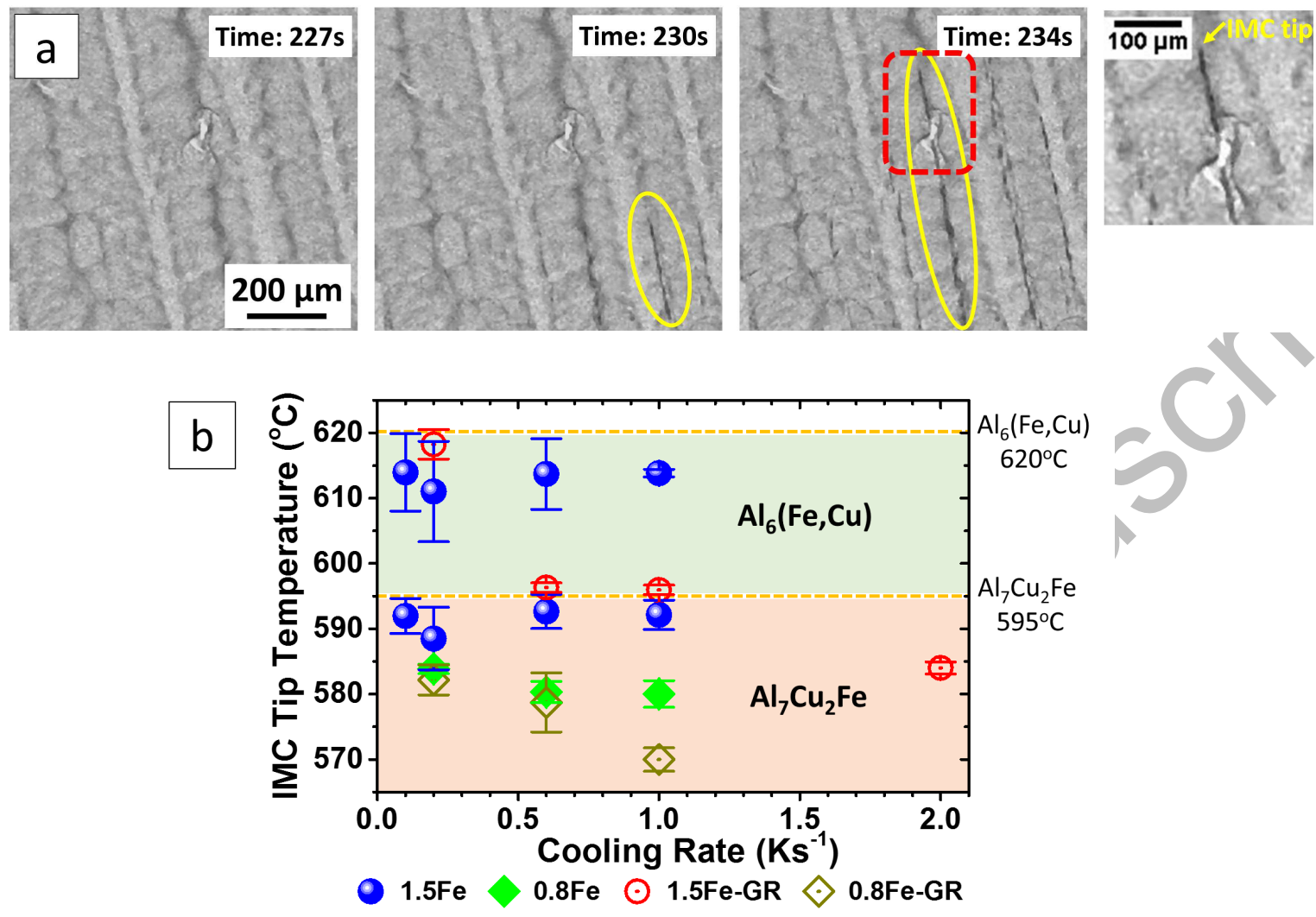

Figure 3: (a) A radiograph sequence of IMC growth at $0.2 \mathrm{Ks}^{-1}$ in $0.8 \mathrm{Fe}$, with zoomed-in image showing the IMC tip. Time $t=0$ was set when the $\alpha$-Al dendrite tips first appeared at the bottom of the field of view. (b) IMC tip temperature at different cooling rates for $1.5 \mathrm{Fe}, 0.8 \mathrm{Fe}, 1.5 \mathrm{Fe}-\mathrm{GR}$ and $0.8 \mathrm{Fe}-\mathrm{GR}$, with labels indicating different $\mathrm{IMC}$ phase populations and literature values of $\mathrm{Al}_{6}(\mathrm{Fe}, \mathrm{Cu})$ [22] and $\mathrm{Al}_{7} \mathrm{Cu}_{2} \mathrm{Fe}$ [11] formation temperatures determined by thermal analysis.

between $580^{\circ} \mathrm{C}$ and $585^{\circ} \mathrm{C}$, regardless of cooling rate.

$0.8 \mathrm{Fe}-\mathrm{GR}$ showed an initial band of IMC tip temperatures in the range $580^{\circ} \mathrm{C}$ to $582^{\circ} \mathrm{C}$ at $0.2 \mathrm{Ks}^{-1}$ and $0.6 \mathrm{Ks}^{-1}$, comparable with those of the non-grain refined $0.8 \mathrm{Fe}$, but IMC tip temperatures then reduced to $570{ }^{\circ} \mathrm{C}$ when the cooling rate increased further to $1 \mathrm{Ks}^{-1}$. In contrast to its non-grain refined counterpart, which showed simultaneously two bands of IMC tip temperatures, $1.5 \mathrm{Fe}-\mathrm{GR}$ showed only a narrow band of IMC tip temperatures at a given cooling rate, the mean of which decreased steadily 140 with cooling rate, from $\sim 620^{\circ} \mathrm{C}$ at $0.2 \mathrm{Ks}^{-1}$ to $\sim 585^{\circ} \mathrm{C}$ at $2 \mathrm{Ks}^{-1}$.

Because radiographic data could not provide sufficient contrast variations between 


\begin{tabular}{cccc}
\hline Phase & Element & Concentration (wt.\%) & Fe:Cu ratio \\
\hline \multirow{3}{*}{$\mathrm{A}$} & $\mathrm{Al}$ & 69 & \\
& $\mathrm{Fe}$ & 23 & $2.6-2.9$ \\
& $\mathrm{Cu}$ & 8 & \\
\hline \multirow{2}{*}{$\mathrm{B}$} & $\mathrm{Al}$ & 54 & $0.4-0.5$ \\
& $\mathrm{Fe}$ & 14 & \\
\hline
\end{tabular}

Total number of points measured: 118

Standard deviation for each element concentration within $\pm 1 \mathrm{wt} . \%$

Table 2: Chemical composition of IMC phases A and B

IMCs to be used as a basis for chemical identification, post-solidification microstructural analysis was performed. Table 2 summarises the results of 118 chemical composition measurements from 34 IMC particles, taken from samples prepared identically to the synchrotron conditions.
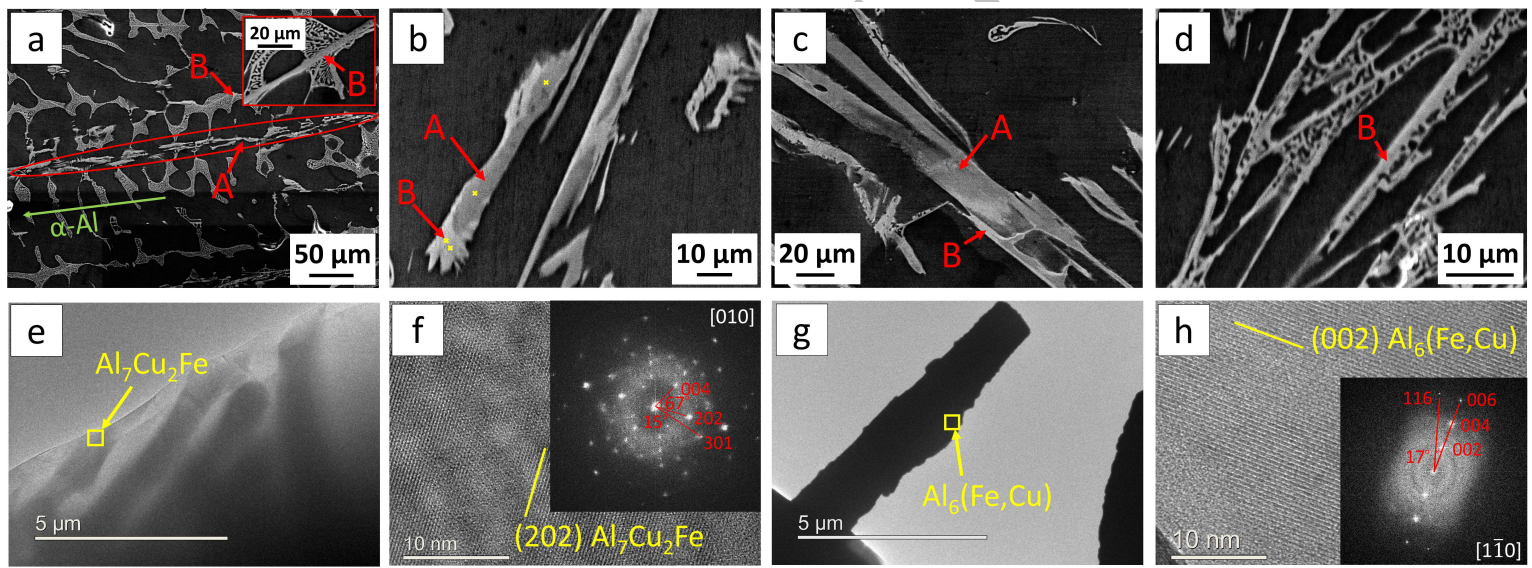

Figure 4: Secondary electron images of: (a) 1.5Fe showing presence of IMC A (in red ellipse), and IMC B (see inset image for detailed morphology) at $1 \mathrm{Ks}^{-1}$, with green arrow indicating the orientation of the primary $\alpha$-Al dendrites, (b) a composite IMC particle with IMC A in the centre and IMC B around the edge in $1.5 \mathrm{Fe}$ at $0.2 \mathrm{Ks}^{-1}$ (yellow spots indicate the positions where EDX spectra were acquired), (c) IMC A particle with small regions near the edge transformed into IMC B in 1.5Fe-GR at $0.2 \mathrm{Ks}^{-1}$, and (d) $1.5 \mathrm{Fe}-\mathrm{GR}$ at $2 \mathrm{Ks}^{-1}$ showing presence of IMC B only (IMC A: $\mathrm{Al}_{6}(\mathrm{Fe}, \mathrm{Cu}$ ); IMC B: $\mathrm{Al}_{7} \mathrm{Cu}_{2} \mathrm{Fe}$ ). Bright field TEM images of (e) $\mathrm{Al}_{7} \mathrm{Cu}_{2} \mathrm{Fe}$ (dark needles) and (g) $\mathrm{Al}_{6}(\mathrm{Fe}, \mathrm{Cu}$ ) (yellow squares indicate the positions where HR-TEM images were acquired); HR-TEM images of (f) $\mathrm{Al}_{7} \mathrm{Cu}_{2} \mathrm{Fe}$

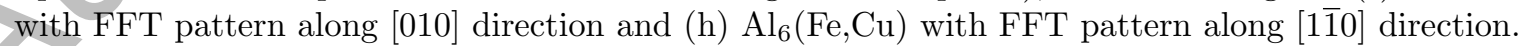

In 1.5Fe, two different needle-like IMCs (A and B) formed at cooling rates between $0.2 \mathrm{Ks}^{-1}$ and $1 \mathrm{Ks}^{-1}$ (Fig. $4 \mathrm{a}$ ), and these two populations correlated with the "highT" and "low-T" IMCs in Fig. 3b. Chemical composition measurements showed that 


\begin{tabular}{lcccc}
\hline Phase & Plane & Measured $(\mathbf{n m})$ & Literature $(\mathbf{n m})$ & Ref. \\
\hline $\mathrm{Al}_{7} \mathrm{Cu}_{2} \mathrm{Fe}$ & 004 & 0.372 & 0.370 & {$[23]$} \\
& 202 & 0.293 & 0.291 & \\
& 301 & 0.210 & 0.209 & \\
\hline $\mathrm{Al}_{6}(\mathrm{Fe}, \mathrm{Cu})$ & 002 & 0.449 & 0.439 & {$[25]$} \\
& 220 & 0.250 & 0.244 & \\
& 222 & 0.219 & 0.213 & \\
& 116 & 0.146 & 0.140 & \\
\hline
\end{tabular}

Table 3: Measured and literature interplanar $d$-spacings for $\mathrm{Al}_{7} \mathrm{Cu}_{2} \mathrm{Fe}$ and $\mathrm{Al}_{6}(\mathrm{Fe}, \mathrm{Cu})$.

high- $\mathrm{T}$ phase $\mathrm{A}$ corresponded to $\mathrm{Al}_{6}(\mathrm{Fe}, \mathrm{Cu})(70 \mathrm{Al}-22 \mathrm{Fe}-8 \mathrm{Cu}$ (wt.\%), Fe:Cu ratio: 2.8 , [22 24]). Low-T phase B corresponded to $\mathrm{Al}_{7} \mathrm{Cu}_{2} \mathrm{Fe}$ (51Al-15Fe-34Cu (wt.\%), Fe:Cu ratio: 0.4). Composite needles of the two phases were also frequently observed in Al$10 \mathrm{Cu}-1.5 \mathrm{Fe}$ (Fig. 4b), with the lower temperature $\mathrm{Al}_{7} \mathrm{Cu}_{2} \mathrm{Fe}$ around the edge of the higher temperature $\mathrm{Al}_{6}(\mathrm{Fe}, \mathrm{Cu})$ centre.

1.5Fe-GR solidified at 0.2 to $1 \mathrm{Ks}^{-1}$ showed predominantly high- $\mathrm{T} \mathrm{Al}_{6}(\mathrm{Fe}, \mathrm{Cu})$, with particles showing edge regions partially transformed or nucleating the low-T IMC $\mathrm{Al}_{7} \mathrm{Cu}_{2} \mathrm{Fe}$ (Fig. 4c). In contrast, the same $1.5 \mathrm{Fe}-\mathrm{GR}$ solidified at the higher rate of $2 \mathrm{Ks}^{-1}$ formed only low- $\mathrm{T}_{7} \mathrm{Cu}_{2} \mathrm{Fe}$ (Fig. 4 $\mathrm{d}$ ). By considering the tip temperature data in Fig. 3b, this change in IMC phase population can be qualitatively correlated with the progressive decrease in the IMC tip temperature.

Figs. 4e and $4 \mathrm{~g}$ show bright field TEM images, and Figs. 4 and $4 \mathrm{~h}$ show HR-TEM images of $\mathrm{Al}_{7} \mathrm{Cu}_{2} \mathrm{Fe}$ and $\mathrm{Al}_{6}(\mathrm{Fe}, \mathrm{Cu})$, respectively. Table 3 lists the measured interplanar $d$-spacings for the two IMCs, which were in good agreement with the literature $[23,25]$.

Combining the SEM/EDX and HR-TEM findings, Fig. 3b is labelled to indicate 165 the regions of the predominant IMC populations for all experiments with respect to alloy composition, cooling rate and grain refiner addition.

According to previous studies of the Al-Cu-Fe system using thermal analysis [11, 
22, 23, the expected phase transformations in $1.5 \mathrm{Fe}$ are:

$$
\begin{aligned}
& \mathrm{L} \rightarrow \alpha-\mathrm{Al} \\
& \mathrm{L} \rightarrow \alpha-\mathrm{Al}+\mathrm{Al}_{6}(\mathrm{Fe}, \mathrm{Cu}) \\
& \mathrm{L}+\mathrm{Al}_{6}(\mathrm{Fe}, \mathrm{Cu}) \rightarrow \alpha-\mathrm{Al}+\mathrm{Al}_{7} \mathrm{Cu}_{2} \mathrm{Fe} \\
& \mathrm{L} \rightarrow \alpha-\mathrm{Al}+\mathrm{Al}_{7} \mathrm{Cu}_{2} \mathrm{Fe}
\end{aligned}
$$

while in $0.8 \mathrm{Fe}$ only reactions $\mathrm{R} 1$ and $\mathrm{R} 4$ were expected because of the lower Fe concentration. $1.5 \mathrm{Fe}$ formed both high- $\mathrm{T} \mathrm{Al}_{6}(\mathrm{Fe}, \mathrm{Cu})$ and low- $\mathrm{T} \mathrm{Al}_{7} \mathrm{Cu}_{2} \mathrm{Fe}$ at all cooling rates from $0.1 \mathrm{Ks}^{-1}$ to $1 \mathrm{Ks}^{-1}$. The estimated high- $\mathrm{T} \mathrm{Al} \mathrm{Al}_{6}(\mathrm{Fe}, \mathrm{Cu})$ tip temperatures (Fig. 3b) were in good agreement with the starting temperature of reaction R2 (i.e. the $\mathrm{Al}_{6}(\mathrm{Fe}, \mathrm{Cu})$ formation temperature) of $620^{\circ} \mathrm{C}$ determined by Phillips et al. [22] using thermal analysis at $0.08 \mathrm{Ks}^{-1}$ for an alloy composition of $10 \mathrm{wt} \% \mathrm{Cu}$ and $1.5 \mathrm{wt} \%$ Fe. Thus, Fig. 3b suggests an $\mathrm{Al}_{6}(\mathrm{Fe}, \mathrm{Cu})$ tip undercooling of $\sim 5^{\circ} \mathrm{C}$. The estimated tip temperatures for low- $\mathrm{T} \mathrm{Al}_{7} \mathrm{Cu}_{2} \mathrm{Fe}$ showed good agreement with the equilibrium ternary peritectic (invariant) reaction temperature in $\mathrm{Al}-\mathrm{Cu}-\mathrm{Fe}$ of $595{ }^{\circ} \mathrm{C}$ [11]. Support for the peritectic reaction was provided by the frequent observation of $\mathrm{Al}_{7} \mathrm{Cu}_{2} \mathrm{Fe}$ formed around the edge of $\mathrm{Al}_{6}(\mathrm{Fe}, \mathrm{Cu})$, such as that shown in Fig. 4 $4 \mathrm{~b}$. When grain refiner was added, high- $\mathrm{T} \mathrm{Al}_{6}(\mathrm{Fe}, \mathrm{Cu})$ was formed at all but the higher cooling rate of $2 \mathrm{Ks}^{-1}$, which instead formed $\mathrm{Al}_{7} \mathrm{Cu}_{2} \mathrm{Fe}$. However, the $\mathrm{Al}_{6}(\mathrm{Fe}, \mathrm{Cu})$ tip temperature now decreased with increasing cooling rate. For example, at the relatively high cooling rate of $1 \mathrm{Ks}^{-1}$, $\mathrm{Al}_{6}(\mathrm{Fe}, \mathrm{Cu})$ grew at $597^{\circ} \mathrm{C}$, representing an undercooling of $23^{\circ} \mathrm{C}$. Although this undercooling is large when compared with typical values of up to a few degrees for primary phases, IMCs undercoolings of up to $30^{\circ} \mathrm{C}$ have been measured by thermal analysis for various Fe-rich IMCs in grain refined Al-Cu-Fe alloys at similar cooling rates in the range $0.2 \mathrm{Ks}^{-1}$ to $0.8 \mathrm{Ks}^{-1}$ [12]. Higher undercooling arose because IMC growth became more constrained as the primary $\alpha$ - $\mathrm{Al}$ transitioned from columnar with relatively open inter-dendritic channels to more equiaxed with more convoluted inter-dendritic liquid 
channels.

By using synchrotron X-ray radiography and a carefully controlled furnace, a method has been developed to estimate the real-time temperature at any point in the field of view, and this method was applied to obtain data on the tip temperature and phase selection in directional solidified $\mathrm{Al}-\mathrm{Cu}-\mathrm{Fe}$ alloys from 47 experiments and 203 IMCs. IMC tip temperatures indicated two Fe-rich IMCs that were identified by post-solidification microscopy as $\mathrm{Al}_{6}(\mathrm{Fe}, \mathrm{Cu})$ and $\mathrm{Al}_{7} \mathrm{Cu}_{2} \mathrm{Fe}$. Grain refiner additions increased the cooling rate sensitivity of the IMC tip undercooling, relating to the ease of growth in inter-dendritic channels. Thus, by using grain refiner additions together with a higher cooling rate, IMC growth was delayed to significantly lower temperatures. Although developed for Al-Cu-Fe alloys in the present work, the in-situ thermal field calibration and temperature estimation method may find wide applicability in radiographic studies.

\section{Acknowledgements}

This work was supported by EPSRC (UK) under grant number EP/N007638/1 (LiME - Liquid Metal Engineering). This work was enabled by synchrotron beamtime at Diamond Light Source B16 (Experiment No. MT9140 and MT8635).

\section{References}

[1] E. Liotti, A. Lui, R. Vincent, S. Kumar, Z. Guo, T. Connolley, I. Dolbnya, M. Hart, L. Arnberg, R. Mathiesen, P. Grant, Acta Mater. 70 (2014) 228-239.

[2] E. Liotti, A. Lui, S. Kumar, Z. Guo, C. Bi, T. Connolley, P. S. Grant, Acta Mater. 121 (2016) 384-395.

[3] B. Kim, S. Lee, S. Lee, H. Yasuda, Mater. Trans. 53 (2) (2012) 374-379. 
[4] A. Bjurenstedt, D. Casari, S. Seifeddine, R. H. Mathiesen, A. K. Dahle, Acta Mater. 130 (2017) 1-9.

[5] F. Wang, D. Eskin, J. Mi, C. Wang, B. Koe, A. King, C. Reinhard, T. Connolley, Acta Mater. 141 (2017) 142-153.

[6] W. Xu, I. Tzanakis, P. Srirangam, W. Mirihanage, D. Eskin, A. Bodey, P. Lee, Ultrason. Sonochem. 31 (2016) 355-361.

[7] ASM International Handbook, Vol. 2, 1990.

[8] L. Backerud, E. Krol, J. Tamminen, Skanaluminium (Organization : Norway), American Foundrymen's Society., Skanaluminium, Universitetsforlaget AS, 1986.

[9] C.-J. Tseng, S.-L. Lee, S.-C. Tsai, C.-J. Cheng, J. Mater. Res. 17 (09) (2002) $2243-2250$.

[10] M. Talamantes-Silva, A. Rodríguez, J. Talamantes-Silva, S. Valtierra, R. Colás,

[11] K. Liu, X. Cao, X. G. Chen, Metall. Mater. Trans. A Phys. Metall. Mater. Sci. 42 (7) (2011) 2004-2016.

[12] K. Liu, X. Cao, X.-G. Chen, Metall. Mater. Trans. A 44 (2) (2012) 682-695.

[13] W.-W. Zhang, B. Lin, D.-T. Zhang, Y.-Y. Li, Mater. Des. 52 (2013) 225-233.

[14] S. C. Wang, M. J. Starink, Int. Mater. Rev. 50 (4) (2005) 193-215.

[15] C.-J. Tseng, S.-L. Lee, T.-F. Wu, J.-C. Lin, Mater. Trans. JIM 41 (6) (2000) $708-713$.

[16] A. Bolouri, K. Liu, X. G. Chen, Metall. Mater. Trans. A Phys. Metall. Mater. Sci. 47 (12) (2016) 6466-6480. 
[25] L. K. Walford, Acta Crystallogr. 18 (2) (1965) 287-291. Ruchert, Mater. Des. 53 (2014) 118-123. (2014) 416-424. 85-92.

[21] J.-L. Pouchou, Mikrochim. Acta 114-115 (1) (1994) 33-52.

[22] H. Phillips, J. Inst. Met. 82 (5) (1954) 197.

[23] G. Phragmén, J. Inst. Met. 77 (6) (1950) 489-551. 993-998.

[18] A. Chemin, D. Marques, L. Bisanha, A. d. J. Motheo, W. W. Bose Filho, C. O. F.

[19] S. Lebouil, J. Tardelli, E. Rocca, P. Volovitch, K. Ogle, Mater. Corros. 65 (4)

[20] A. Chemin, D. Spinelli, W. Bose Filho, C. Ruchert, Procedia Eng. 101 (C) (2015)

[24] P. J. Black, O. S. Edwards, J. B. Forsyth, IUCr, Acta Crystallogr. 14 (9) (1961) 